\title{
The curious genitalic structures of Tancitares michoacanus (Polydesmida, Rhachodesmidae)
}

\author{
Richard L. Hoffman \\ Virginia Museum of Natural History, Martinsville, Virginia 24112, USA \\ Corresponding author: Richard L. Hoffman (richard.hoffman@vmnh.virginia.gov)
}

Academic editor: Pavel Stoev | Received 11 August 2011 | Accepted 19 September 2011 | Published 11 October 2011

Citation: Hoffman RL (2011) The curious genitalic structures of Tancitares michoacanus (Polydesmida: Rhachodesmidae). International Journal of Myriapodology 5: 27-33. http://dx.doi.org/10.3897/ijm.5.1899

\begin{abstract}
The unusual male and female structures in Tancitares michoacanus Chamberlin, 1942, inadequately documented in the original description, are redescribed and illustrated from type material. The species is reported from a locality in Colima, Mexico, the second known for this species. Pararhachistes Pocock, 1909, is suggested as a possible closely related taxon.
\end{abstract}

\section{Keywords}

Diplopoda, Polydesmida, Rhacodesmidae, Tancitares, Mexico, genitalia

\section{Introduction}

Millipeds of the family Rhachodesmidae lay claim to our attention in several notable respects. The family itself, endemic to Middle America, appears to have affinities to the likewise restricted taxa Sphaeriodesmidae and Holistophallidae but its derivation in a phylogenetic sense is by no means established. Aside from the diversity expressed in the vivid colors of orange, red, green, and blue, rhachodesmids have improvised a number of structural innovations that collectively suggest a derived evolutionary status for the family and invite a closer documentation of such traits than heretofore accorded them.

Material discovered during curation of the VMNH milliped collection provided the opportunity for examination of Tancitares, a monotypic rhachodesmid genus based on T. michoacanus, described by R. V. Chamberlin in 1942 and still known only from 
the original specimens. Although Chamberlin's description was surprisingly detailed, the male genitalia were represented only by a small sketch and the corresponding female structures by a few brief comments. Since there seems little prospect that the family will be subject of a systematic revision in the foreseeable future, some results of my investigation may be justified in view of the specialized structure of the gonopods that suggests a disjunct position for this genus.

\section{Family Rhachodesmidae Carl}

\section{Genus Tancitares Chamberlin}

http://species-id.net/wiki/Tancitares

Tancitares Chamberlin, 1942, Proc. Biol. Soc. Washington 55: 58. - Loomis, 1968, U. S. Nat. Mus. Bull. 266: 41. - Hoffman, 1999, Va. Mus. Nat. Hist. Spec. Publ. 8: 429.

Type species. Tancitares michoacanus Chamberlin, by original designation and monotypy.

Diagnosis. Males of the type species are distinguished from all other rhachodesmids by the occurrence of digitiform accessory processes on the coxae of the second pair of legs (Fig. 3), and by the reduction of the soleniferous element of the gonotelopodite to a vestigial basal remnant, with hypertrophy of the remaining telopodite (Fig. 7). Females may be recognized by the elongated tubular form of the female genitalia and modified pleurosternal region of the $3^{\text {rd }}$ segment (Fig. 10).

Range. The genus is known only from the western part of the Mexican transverse volcanic belt in Michoacán and Colima.

Affinities. Among the ranks of established rhachodesmid genera, only one is a possible close relative of Tancitares: the rather poorly-known genus Pararhachistes Pocock (1909) which was proposed for two species (P. elevatus and P. vertebratus) from the coastal mountains of Guerrero. Pocock's illustrations (1909: pls. 12,13) portray a general similarity in body form, the large size of the gonopod aperture, and small secondary processes on the male $2^{\text {nd }}$ coxae. The figure of the gonopod of elevatus (reproduced here as Fig. 8), indicates a slender, sinuous process just distad of the basal fossa that might be the homologue of the solenomere in Tancitares. Unfortunately the type material of Pocock's two species was not found during several personal searches of the British Museum myriapod collection, and may be presumed lost, denying the opportunity for an examination with higher magnification. Eventually topotypic material may become available. A third nominal species, $P$. amblus Chamberlin (1942b) is known to me from a male paratype. This species is not congeneric with those named by Pocock, differing inter alia in that the efferent duct extends to the apex of the telopodite and is not carried on a slender basal solenomere. Lastly, two other species (galeanae and potosinus) named in Pararhachistes by Chamberlin (1943), were based on female specimens which cannot be assigned to any genus with present knowledge of this family. Their geographic origin (San Luis Potosí and Nuevo León) argues against their placement in either Pararhachistes or Tancitares. 


\section{Tancitares michoacanus Chamberlin}

http://species-id.net/wiki/Tancitares_michoacanus

Figs $1-7$, 9, 10

Tancitares michoacanus Chamberlin, 1942, Proc. Biol. Soc. Washington, 55: 58, fig. 7. Male holotype, one male and two female topoparatypes (USNM), one male paratype (VMNH) from Pedregal, 6000 ft., Cerro Tancítaro, Michoacán, Mexico; H. Hoogstraal leg. 28 June 1941 (Comment 1).

Material. The type series, also: Mexico: Colima: "8 mi. NW of Colima”, 25 July 1963, Donald R. Whitehead (VMNH 1/0).

Description. Paratype male (VMNH), length not measurable (specimen fragmented), W ca. $2.8 \mathrm{~mm}$; body parallel-sided over most of length, collum and segments 2-4 slightly narrower than 5. Color, shortly after preservation (teste Chamberlin 1942a): dorsally brown, with caudal margin of metaterga medially yellow, paranota of segments 1-5 and the poriferous paranota thereafter yellow, legs light brown proximally, yellowish distally.

Head and gnathochilarium unmodified. Paranota relatively small and set high on sides, overlapping on anterior segments, moderately separated at midbody, slightly elevated above horizontal; anterior and posterior corners broadly rounded on anterior segments (Fig. 1), posterior corners of poriferous segment beyond midbody notably beveled, marginal peritreme terminating at level of ozopores, not continued to posterior angle (Fig. 2). Pore distribution normal. Metaterga without transverse sulcus, surface densely and coarsely punctate, becoming granulate on paranota, caudal edge with a row of 6 to 8 small tubercles. Stricture not costulate, anterior edge sharply defined. Segment 20 broadly triangular, paraprocts and hypoproct unmodified. Segments ventrally elevated as podosterna, each with moderately deep transverse groove, no subcoxal projections. Sides of metazona notably coriarious. Stigmata small, rounded, in normal polydesmoid positions. Legs long, sparsely setose, without distal tibial or tarsal pads or other modifications.

Sterna of anterior segments narrow, unmodified. Coxae of $2^{\text {nd }}$ pair of legs (Fig. 3) with prominent, digitiform, anteriorly-directed processes originating at bases of gonapophyses, latter long, slender, distally setose.

Gonopod aperture large, subquadrate, narrowing both stricture and prozonum, sternum of $7^{\text {th }}$ segment with two conical setose processes (Fig. 4). Gonopods retracted into body cavity, only apices of coxae visible; no median sternal sclerite. Transverse muscle between sternal apodemes not evident. Coxae reduced in size, without setae, no trace of cannula or its internal musculature (Comment 2). Telopodites long and slender, extending anterior between legs of $5^{\text {th }}$ segment, their apices interlocked (Fig. 4). Basal region globose, with large internal chamber lined with dense short setae, opening on mesal side of base. Edge of cavity/fossa continued as an acuminate, recurved process carrying the efferent duct (Fig. 7). Remainder of telopodite a slender, curved branch with acute terminus and a sigmoidally curved, retrorse subapical process (Fig. 6) on mesal side. 

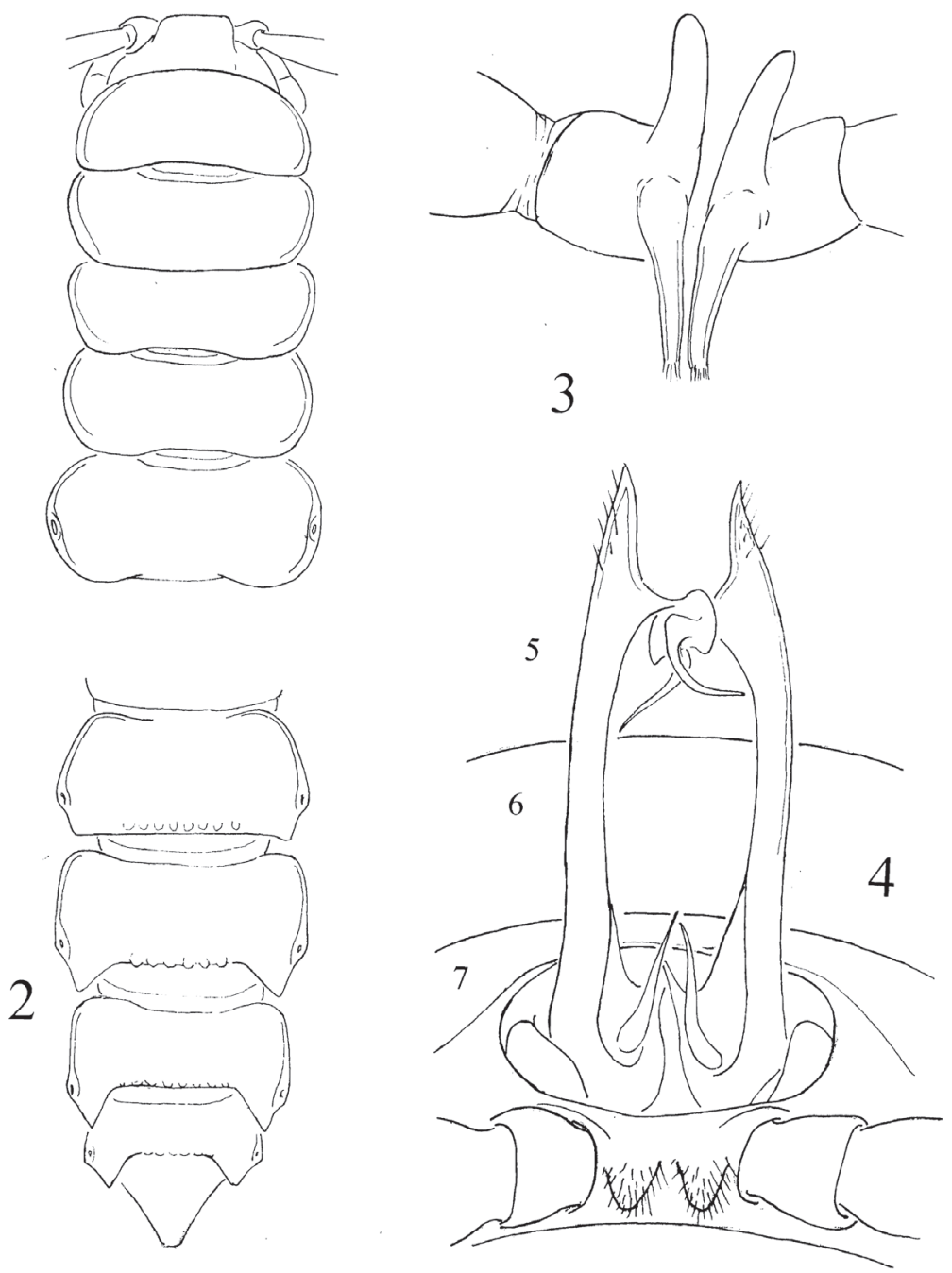

Figures I-4. Tancitares michoacanus, structural details. I Head and metaterga of segments 1-5, dorsal aspect $\mathbf{2}$ Segments 16-20, dorsal aspect, showing peritremata ending at ozopores 3 Coxae of $2^{\text {nd }}$ pair of legs of male, ventral aspect, showing large digitiform processes directed anteriad $\mathbf{4}$ Gonopods in situ, ventral aspect, small numbers represent the approximate extent of segments $5-7$, leg bases not indicated. Drawings from male topoparatype.

Female genitalia notably modified: sterna region of $3^{\text {rd }}$ segment strongly prolonged ventrad forming a sheath partly surrounding coxae of $2^{\text {nd }}$ legs and cyphopods, coxae prolonged ventrad as subconical processes (Fig. 9). Cyphopods elongate, tubular, entirely membranous, no basal sclerotized element (receptacle) observed (Fig. 10) (valves may be strongly reduced and concealed at ends of tubular region) (Comment 3). 


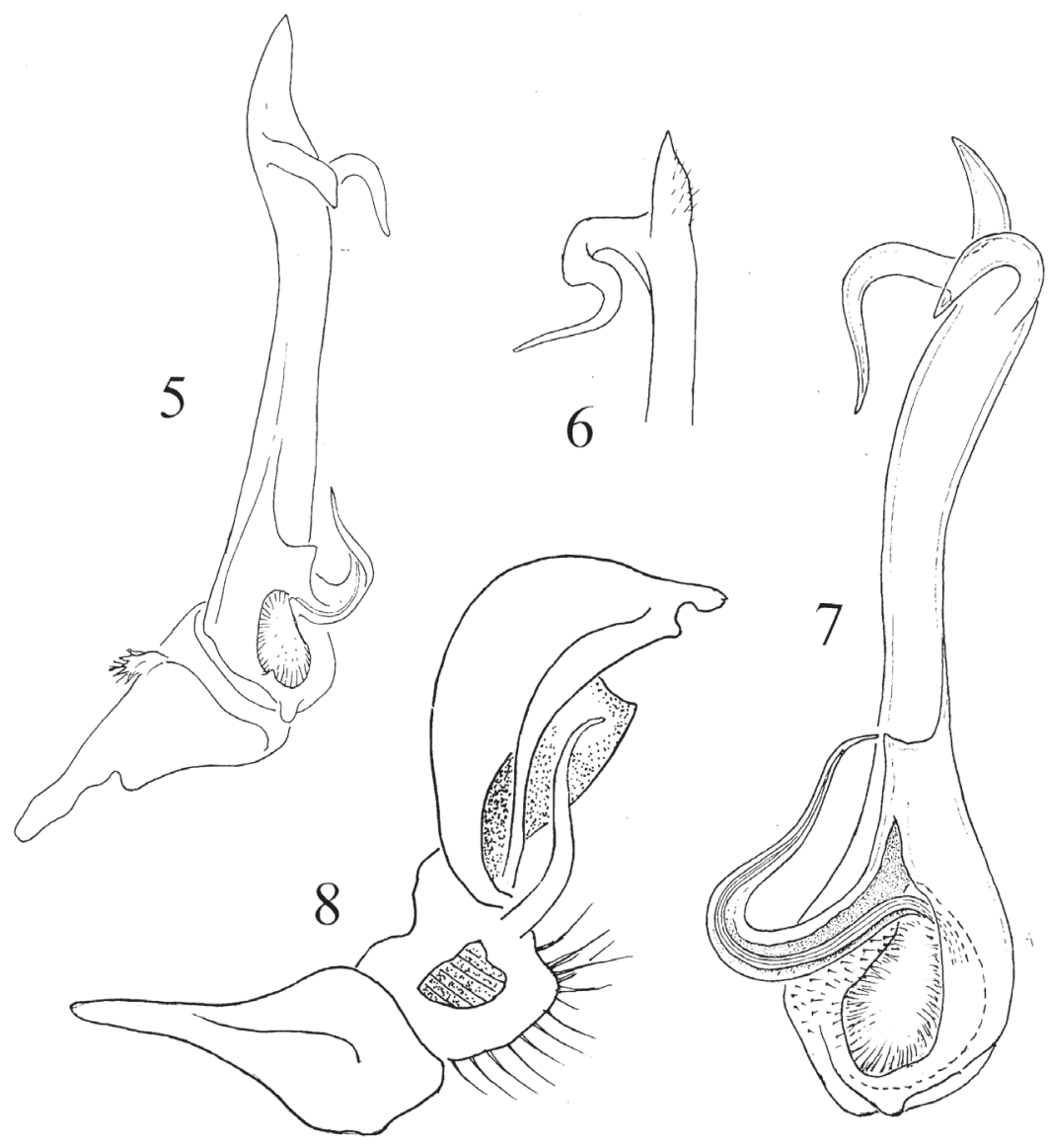

Figures 5-8. Tancitares michoacanus, gonopod structure. 5 Left gonopod, approximate mesal aspect 6 Apex of telopodite in a different aspect to show entire curvature of subterminal process $\mathbf{7}$ Telopodite of right gonopod, specimen from Colima, drawn from cleared microscope preparation to show details of basal region, somewhat enlarged over scale of Fig. 5. Figures 5-6 from male topoparatype 8 Pararhachistes elevatus Pocock, mesal aspect of left gonopod, for comparison with Fig. 5. Enlarged and redrawn from Fig. 7c, Plate 13, in Pocock 1909.

\section{Comments}

1. Cerro Tancítaro $\left(19.42^{\circ} \mathrm{N}, 102.3^{\circ} \mathrm{W}\right)$ is immediately north of the town of Tancítaro, and approximately $41 \mathrm{~km}$ west of Uruapan; it is now embraced by the Parque Nacional del Pico de Tancítaro. The higher elevations are invested in an open, dispersed fir forest. I have not located the local place name Pedregal, at 6000 $\mathrm{ft}$. it must be somewhere near the base of the mountain which attains an elevation of $3800 \mathrm{~m}$ ASL. 

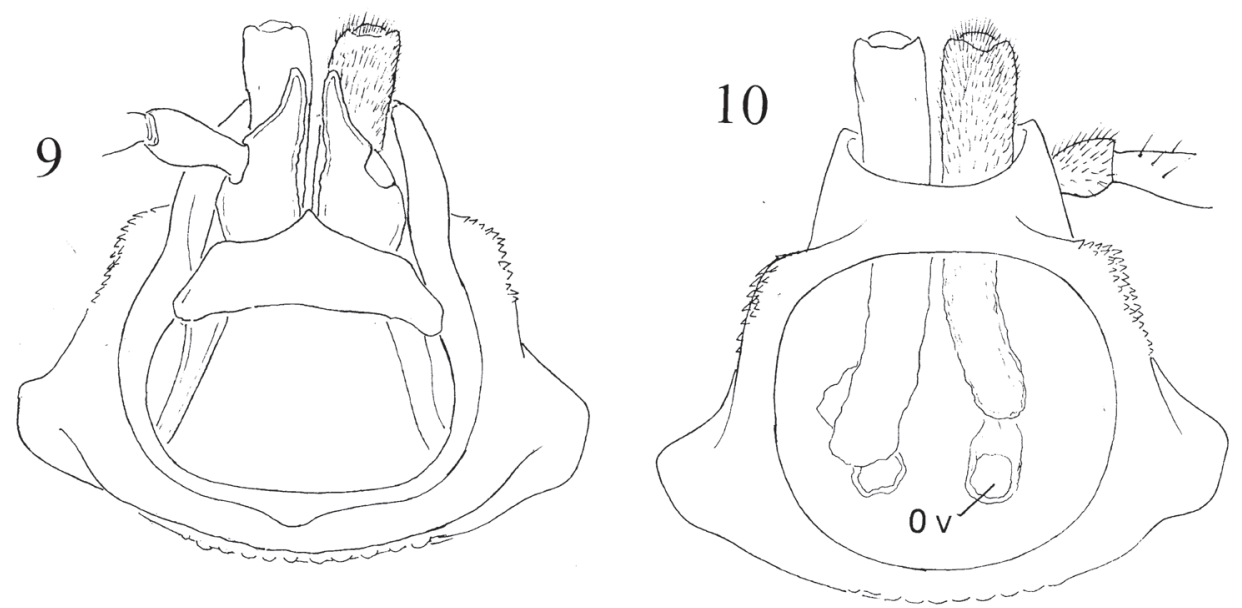

Figures 9-10. Tancitares michoacanus, segment 3 and female genitalia. 9 Anterior aspect of segment with genitalia and leg bases in place $\mathbf{1 0}$ Posterior aspect showing ventral prolongation of metazonum, elongate, tubular cyphopods, and proximal end of oviducts (ov). Drawings from female topoparatype.

2. The loss of the normal polydesmidan cannula is accompanied in all known rhachodesmids by the development on the median side of the telopodite of an enlarged cavity (fossa), which leads distally into the efferent duct. While the function of the cannula has yet to be demonstrated, it is my conviction that it serves as a "needle valve" which normally controls flow of a secretion from an internal coxal (and ceolomic) gland into the duct, and can be moved into an "open" position by an inner coxal muscle. In the absence of a cannula, the secretion perhaps is delivered by an alternate delivery system for accumulation in the fossa, or a different secretion is derived from a yet unidentified source. While I believe that Brolemann's perception of a "prostatic" function is entirely plausible, I defer to Prof. Enghoff's recent (2011) proposal of "efferent duct" for the telopodite groove since it does not presume any unproven function. In any event, the secretion conducted by this groove (which occurs in juliform millipeds as well as in callipodidans and polydesmidans), can only have the function of providing nutrition to the emplaced spermatophore, or an enzyme by which it can be dissolved to finalize transfer of contained spermatocytes to the receptacular elements in the female genitalia.

Reduction and displacement of the solenomere to an obscure basal location on the telopodite raises the question of its effectiveness (in whatever function) vis- $\dot{a}$-vis the spermatophore, which from positional anatomy, would most likely be placed at or near the telopodite apex. In other genera of this family, the efferent duct extends to the true distal extremity of the telopodite.

An anatomically similar configuration occurs, to my knowledge, only in the sphaeriodesmid group Desmoninae (cf. Hoffman 1979: figs. 7, 8 for comparative illustration). While rhachodesmids and sphaeriodesmids share the elongated, distally laciniate gonapophyses of the male $2^{\text {nd }}$ coxae, the two families are not thought to be closely 
related and the similarity in gonopod structure is surely a random homoplasy rather than a defensible synapomorphy.

3. The term "cyphopod" as applied to the complex of sclerotized elements through which the oviducts terminate in most diplopods is objectionable in its implication of derivation from a modified walking leg, and is disavowed by chiefly European investigators who prefer the term "vulva" as an alternative descriptor without functional overtones. Although I believe that Demange (1961) clearly demonstrated by study of the musculature, the identity of the female genitalia as modified legs, I use "cyphopods" in a default sense only until a morphologically precise alternative is contrived. "Vulva" should be restricted to its original application as referring to a mammalian anatomical region, not structure, neither homologous nor analogous with the millipede structure so designated.

\section{References}

Chamberlin RV (1942a) New millipeds from Michoacan. Proceedings of the Biological Society of Washington 55: 57-62.

Chamberlin RV (1942b) On centipeds and millipeds from Mexican caves. Bulletin of the University of Utah 33(4): 3-19.

Chamberlin RV (1943) On Mexican millipeds. Bulletin of the University of Utah, 34(7): 3-103.

Demange J-M (1961) Recherches sur la segmentation du tronc des chilopodes et des diplopodes chilognathes (Myriapodes). Mémoires du Muséum National d'Histoire Naturelle, ser. A 44: 1-188.

Enghoff H. (2011) East African giant millipedes of the tribe Pachybolini (Diplopoda, Spirobolida, Pachybolidae). Zootaxa 2753: 1-41.

Hoffman RL (1979) On the status of the milliped genus Cyphodesmus Peters, 1864 (Sphaeriodesmidae). Revue suisse de Zoologie 86: 3-9.

Hoffman RL (1999) Checklist of the Millipeds of North and Middle America. Virginia Museum of Natural History Special Publication 8: 1-584.

Loomis HF (1966) A Checklist of the Millipeds of Mexico and Central America. United States National Museum Bulletin 266: 1-137.

Pocock RI (1903-10) Chilopoda and Diplopoda. In: Salvin O, Godwin FD (Eds) Biologia Centrali-Americana. Taylor \& Francis, London. Fascicle treating Rhachodesmidae published December, 1909, 41-217. 